\title{
First record of predation on the bat Carollia perspicillata by the false coral snake Oxyrhopus petolarius in the Atlantic Rainforest
}

\author{
Frederico Gustavo Rodrigues França * \\ Rafaella Amorim de Lima \\ Universidade Federal da Paraíba, Centro de Ciências Aplicadas e Educação \\ Departamento de Engenharia e Meio Ambiente, CEP 58297-000, Rio Tinto - PB, Brasil \\ * Corresponding author \\ fredericofranca@me.com
}

Submetido em 23/03/2012

Aceito para publicação em 28/06/2012

\section{Resumo}

Primeiro registro de predação do morcego Carollia perspicillata pela falsa coral Oxyrhopus petolarius na Mata Atlântica. Registros de morcegos como presas de serpentes são bastante escassos na literatura, mas trabalhos recentes têm evidenciado que essa predação não parece ser um fenômeno incomum. Apresentamos aqui o primeiro registro de predação do morcego Carollia perspicillata pela falsa coral Oxyrhopus petolarius em uma área de Mata Atlântica na região Nordeste do Brasil.

Palavras-chave: Dieta; Falsa coral; Morcegos; Serpentes

\section{Abstract}

Records of bats as prey of snakes are very few in the literature, but recent studies have shown that this predation doesn't seem to be an unusual phenomenon. We present here the first record of predation on the bat Carollia perspicillata by the false coral snake Oxyrhopus petolarius in an Atlantic Rainforest area in the Northeastern Brazil.

Key words: Bats; Diet; False coral snake; Snakes

Although bats are not considered an important component of the diet of most snake species, snake predation on bats does not seem to be an unusual phenomenon (SCHÄTTI, 1984; HASTINGS, 2010). In fact, boids are common predators of bats in the neotropics, with bats having been recorded in the diet of almost all genera (except Eunectes), the most notable being Central American Epicrates (E. angulifer, E. inornatus, and E. subflavus) (HARDY, 1957; RODRÍGUEZ; REAGAN, 1984; KOENIG; SCHWARTZ, 2003) and South American Corallus hortulanus (HENDERSON, 1993; ESBÉRARD; VRCIBRADIC, 2007). Other snakes that reportedly prey on bats include the vipers Bothriechis schlegelii and Bothrops asper (ESBÉRARD; VRCIBRADIC, 2007) and large-sized Colubrinae, such as Elaphe flavirufa, Pantherophis guttatus, Pituophis 
melanoleucus, Pseustes sulphureus, and Spilotes pullatus (DAVIS, 1951; RAINWATER; PLATT, 1999; RUFINO; BERNARDI, 1999; ESBÉRARD; VRCIBRADIC, 2007). Finally, among the many Dipsadinae snakes, bats have been recorded only in the diet of Siphlophis cervinus, which was reported to have eaten an insectivorous bat Myotis sp., ingested tail-first (PRUDENTE et al., 1996).

In the material kept in the Herpetological Collection of Universidade Federal da Paraiba (CHUFPB), Brazil, we found an adult female calico false coral snake Oxyrhopus petolarius (Linnaeus, 1758) (UFPB 2451; Figure 1; 635mm snout-vent length and $820 \mathrm{~mm}$ total length) collected in Estacao Ecologica Pau-Brasil, Porto Seguro, Bahia, Brazil, which had an entire adult bat specimen in its stomach (Figure 1). The prey bat was identified by the Chiroptera specialists Alfredo Ricardo Langguth Bonino and Patrício Adriano da Rocha, from Universidade Federal da Paraiba (UFPB), as seba's short-tailed bat Carollia perspicillata (Linnaeus, 1758) (Chiroptera, Phyllostomidae). The bat was $23 \mathrm{~cm}$ in total length, it weighed $18 \mathrm{~g}$, and it was ingested tail-first.

Oxyrhopus petolarius is widely distributed throughout Central and South Americas (SAVAGE; VILLA, 1986; MARKEZICH, 2002; LYNCH, 2009; MACCULLOCH et al., 2009). In Brazil, O. petolarius inhabits forested areas in Cerrado (VAZ-SILVA et al., 2007), Atlantic Rainforest (SANTANA et al., 2008), and Amazonia (BERNARDE; MACHADO, 2000). Information on this species' diet is few in the literature, and is typically claimed as mainly consisting of lizards, rodents, and occasionally birds (ANDRADE; SILVANO, 1996; BERNARDE; MACHADO, 2000). Carollia perspicillata is a frugivorous bat species that inhabits both moist evergreen and dry deciduous forests, usually in caves, hollow trees, tunnels, road culverts, and, less commonly, in rock crevices, under leaves and in buildings (CLOUTIER; THOMAS, 1992). Although, as far as we know, there were no records of snakes preying on $C$. perspicillata, other animals have been reported to opportunistically prey on this bat, such as the frog Leptodactylus pentadactylus (CASTRO et al., 2011) and the mammals Chrotopterus auritus, Phyllostomus hastatus, Felis silvestris catus, Cerdocyon thous, and
Chironectes minimus (BREVIGLIERI; PEDRO, 2010; NOVAES et al., 2010).

FIGURE 1: A live, adult Oxyrhopus petolarius from the Brazilian Atlantic Rainforest (A). Dorsal view of Oxyrhopus petolarius (UFPB 2451) and the bat Carollia perspicillata found in the snake's stomach (B).
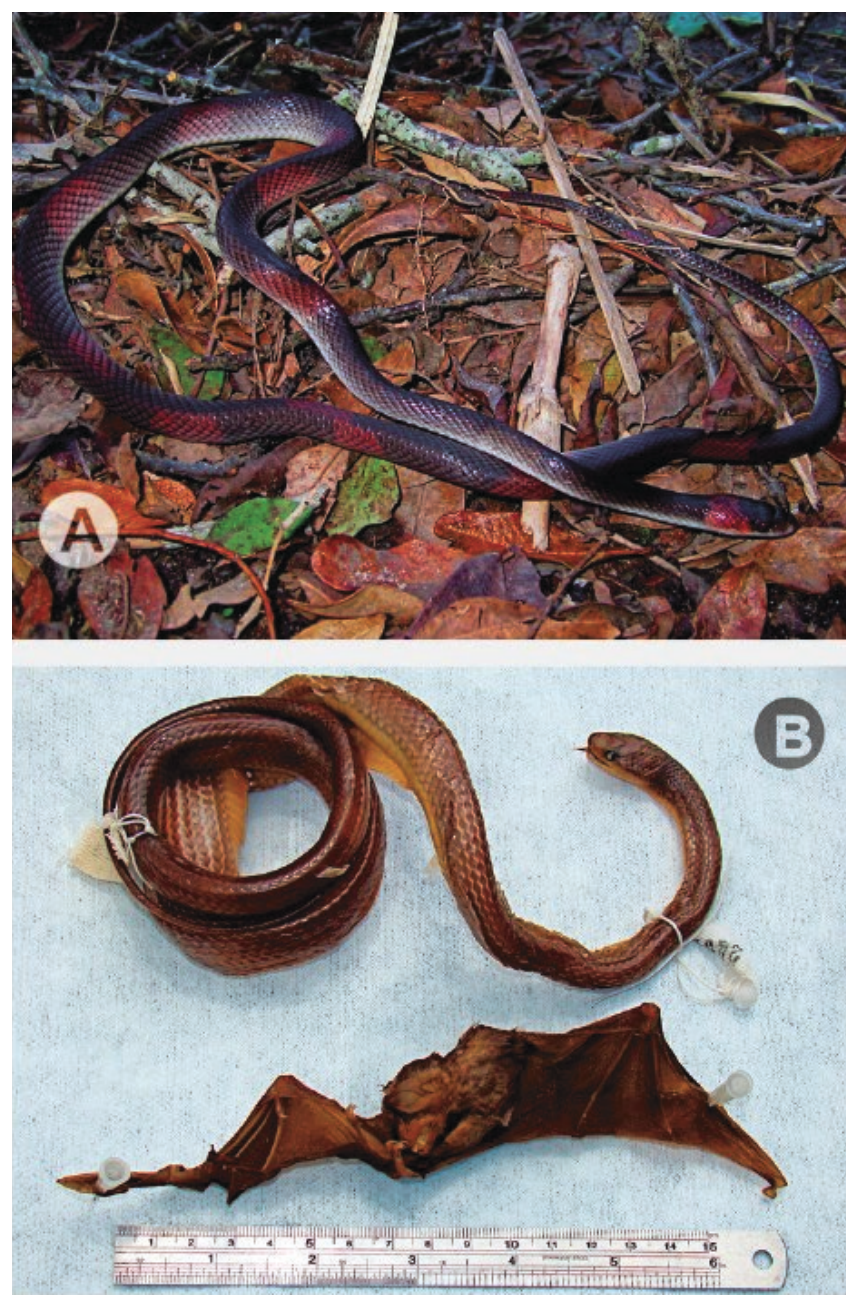

This record corroborates the role of bats as potential prey for snakes and it extends the list of bat predators in Brazil. Preying on bats can involve some risk of injury to the predator (ESBÉRARD; VRCIBRADIC, 2007). However, snakes which use constriction to subdue their prey, such as Oxyrhopus and other Dipsadinae snakes (ANDRADE; SILVANO, 1996), may have reduced risk for injury. Both in our record, with $O$. petolarius, and in the record by Prudente et al. (1996), with Siphlophis cervinus, the bat prey was ingested tail-first, something which suggests that the bat was immobilized prior to ingestion. The most likely scene for this behavior is the 
Colubrid's predation strategy presented by Esbérard and Vrcibradic (2007): these snakes forage at, or near to, cave entrances, and capture bats that are lying on the ground or clinging to cave walls.

\section{Acknowledgements}

The authors thank the financial support from the Brazilian National Council for Scientific and Technological Development (CNPq) (Universal Grant 474250/2010-5). We also thank Gentil Alves Pereira Filho, for the $O$. petolarius photograph, and Donald B. Sheppard, for his valuable suggestions on the final manuscript. Last but not least, thanks to D. L. P. Leite, T. Colston, and J. Carr for their critical review of early versions of the text.

\section{References}

ANDRADE, R. O.; SILVANO, R. A. M. Comportamento alimentar e dieta da "falsa-coral" Oxyrhopus guibei Hoge \& Romano (Serpentes, Colubridae). Revista Brasileira de Zoologia, Curitiba, v. 13, n. 1, p. 143-150, 1996.

BERNARDE, P. S.; MACHADO, R. A. Oxyrhopus petola digitalis (NCN). Prey. Herpetological Review, Salt Lake City, v. 31, n. 4, p. 247-248, 2000

BREVIGLIERI, C. P. B.; PEDRO, W. A. Predação de morcegos (Phyllostomidae) pela cuíca d'água Chironectes minimus (Zimmermann, 1780) (Didelphimorphia, Didelphidae) e uma breve revisão de predação em Chiroptera. Chiroptera Neotropical Brasília, v. 16, n. 2, p. 732-739, 2010.

CASTRO, I. J.; SILVA, C. R.; COSTA, A. J. S.; MARTINS, A. C. M. Predação oportunista de Artibeus planirostris (Spix, 1823) e Carollia perspicillata (Linnaeus, 1758) (Chiroptera, Phyllostomidae) por marsupiais e anuro na APA do Rio Curiaú, Amapá, Brasil. Acta Amazonica, Manaus, v. 41, n. 1, p. 171-174, 2011.

CLOUTIER, D., THOMAS, D. W. Carollia perspicillata. Mammalian Species, Washington, v. 417, p. 1-9, 1992.

DAVIS, W. B. Bat, Molossus nigricans, eaten by the rat snake, Elaphe laeta. Journal of Mammalogy, Lawrence, v. 32, n. 2, p. 219, 1951.

ESBÉRARD, C. E. L.; VRCIBRADIC, D. Snakes preying on bats: new record from Brazil and a review of recorded cases in the Neotropical region. Revista Brasileira de Zoologia, Curitiba, v. 24, p. 848-853, 2007.

HASTINGS, A. K. Natural History Notes. Pantherophis alleghaniensis (Eastern Ratsnake). Diet. Herpetological Review, Salt Lake City, v. 41, n. 3, p. 371, 2010.
HARDY, J. D. Bat predation by the Cuban boa, Epicrates angulifer Bibron. Copeia, Lawrence, n. 2, p. 151-152, 1957.

HENDERSON, R. W. On the diets of some arboreal boids. Herpetological Natural History, Victorville, v. 1, n. 1, p. 91-96, 1993.

KOENIG, S. E.; SCHWARTZ, M. Natural History notes. Epicrates subflavus. Diet. Herpetological Review, Salt Lake City, v. 34, n. 3 , p. 374-375, 2003.

LYNCH, J. D. Snakes of the genus Oxyrhopus (Colubridae: Squamata) in Colombia: taxonomy and geographic variation. Papéis Avulsos de Zoologia, São Paulo, v. 49, n. 25, p. 319-337, 2009.

MACCULLOCH, R. D.; PHILIPPE, A. L.; KOK, J. R.; ERNST, R.; KALAMANDEEN, M. The genus Oxyrhopus (Serpentes: Dipsadidae: Xenodontinae) in Guyana: morphology, distributions and comments on taxonomy. Papéis Avulsos de Zoologia, São Paulo, v. 49, n. 36, p. 487-495, 2009.

MARKEZICH, A. L. New distribution records of reptiles from Western Venezuela. Herpetological Review, Salt Lake City, v. 33, n. 1, p. 69-74, 2002.

NOVAES, R. L. M.; MENEZES JR., L. F.; FAÇANHA, A. C. S.; LOURO, M.; CARDOSO, T. S.; SANT'ANNA, C.; FELIX, S.; SILVARES, R.; SIQUEIRA, A. C.; SOUZA, R. F.; DIAS-DEOLIVEIRA, L. F. C.; AGUIAR, M. V. P. Predação oportunista de morcegos por Cerdocyon thous (Carnivora, Canidae) no sudeste do Brasil. Chiroptera Neotropical, Brasília, v. 16, n. 1 p. 29-31, 2010.

PRUDENTE, A. L. C.; MOURA-LEITE J. C.; MORATO, S. A. A. Alimentação das espécies de Siphlophis Fitzinger (Serpentes, Colubridae, Xenodontinae, Pseudoboini). Revista Brasileira de Zoologia, Curitiba, v. 15, n. 3, p. 375-383, 1996.

RAINWATER, T. R.; PLATT, S. G. Natural History notes. Elaphe flavirufa (Tropical rat snake). Herpetological Review, Salt Lake City, v. 30, n. 1, p. 46, 1999.

RODRÍGUEZ, G.; REAGAN, D. P. Bat predation by the Puerto Rico boa (Epicrates inornatus). Copeia, Lawrence, n. 1, 219-220, 1984.

RUFINO, N.; BERNARDI, J. A. R. Natural History notes. Pseustes sulphureus sulphureus. Diet. Herpetological Review, Salt Lake City, v. 30, n. 1, 103-104, 1999.

SANTANA, G. G.; VIEIRA, W. L. S.; PEREIRA-FILHO, G. A.; DELFIM, F. R.; LIMA, Y. C. C.; VIEIRA, K. S. Herpetofauna em um fragmento de Floresta Atlântica no Estado da Paraíba, Região Nordeste do Brasil. Biotemas, Florianópolis, v. 21, n. 1, p. 75-84, 2008.

SAVAGE, J. M.; VILLA, J. R. Introduction to the herpetofauna of Costa Rica. Introducción a la herptofauna de Costa Rica. Contribution to Herpetology. SSAR, Salt Lake City, n. 3, p. 1-207, 1986.

SCHÄTTI, B. Fledermäuse als nahrung von schlangen. Bonner Zoologische Beiträge, Bonn, v. 35, p. 335-342, 1984.

VAZ-SILVA, W.; GUEDES, A. G.; AZEVEDO-SILVA, P. L.; GONTIJO, F. F.; BARBOSA, R. S.; ALOÍSIO, G. R.; OLIVEIRA, F. C. G. Herpetofauna, Espora Hydroelectric Power Plant, state of Goiás, Brazil. Check List, Rio Claro, v. 3, n. 4, p. 338-345, 2007. 